\title{
Mycobiota and mycotoxins in Portuguese pork, goat and sheep dry-cured hams
}

\author{
Paula Rodrigues $^{1}$ (D) $\cdot$ Diana Silva $^{1} \cdot$ Pedro Costa $^{1} \cdot$ Luís Abrunhosa $^{2} \cdot$ Armando Venâncio $^{2} \cdot$ Alfredo Teixeira $^{1}$ \\ Received: 18 March 2019 / Revised: 30 August 2019 / Accepted: 2 September 2019/Published online: 8 September 2019 \\ (C) Society for Mycotoxin (Research Gesellschaft für Mykotoxinforschung e.V.) and Springer-Verlag GmbH Germany, part of Springer Nature 2019
}

\begin{abstract}
The objectives of the present work were to survey, for the first time, the contamination of Portuguese fresh and dry-cured meat products with ochratoxin $\mathrm{A}(\mathrm{OTA})$ and aflatoxin $\mathrm{B}_{1}\left(\mathrm{AFB}_{1}\right)$, and to determine the fungi potentially responsible for this contamination. A total of 128 samples including pork fresh legs, dry-cured legs and shoulders, as well as goat and sheep dry-cured legs were analysed. Mycological analysis of these samples yielded a total of 630 fungal isolates. Penicillium sp. was the dominant fungal genus in all products (66\% of all isolates). Penicillium nordicum and Aspergillus westerdijkiae were only rarely isolated from pork ham samples. In fresh pork meat, $40 \%$ of the samples were contaminated with OTA at levels below $1 \mu \mathrm{g} / \mathrm{kg}$. In pork dry-cured legs with 20 to 25 months of ripening, $43 \%$ of the samples showed detectable contamination, while $18 \%$ of the shoulder hams were contaminated. OTA was not detected in any of the goat and sheep samples. OTA contamination does not seem to be a risk in small-piece and short-ripe products like goat and sheep legs, but affects longer ripe products like pork legs and shoulders. Although aflatoxigenic fungi were identified, $\mathrm{AFB}_{1}$ was not detected in any sample, and it should not be considered a risk in dry-cured hams.
\end{abstract}

Keywords Penicillium $\cdot$ Aspergillus $\cdot$ Ochratoxin A $\cdot$ Aflatoxins $\cdot$ Food safety $\cdot$ Meat products

\section{Introduction}

Production of pigs, goats and sheep plays an important role in the economy of Portugal, with an average annual contribution of 23,000 $\mathrm{t}$ (Paulos et al. 2015). Bísaro is a highly appreciated breed of pig from the Northeast of Portugal. Serrana and Churra Galega Bragançana are the most important Portuguese goat and sheep breeds, and the production and commercialization of derived products have been promoted as viable strategies for the development of rural economy (Paulos et al. 2015). As such, meat from older animals with low commercial value is also used, usually by being diverted to process and cure with salts (Teixeira et al. 2017), to obtain the highly appreciated dry-cured hams.

Paula Rodrigues

prodrigues@ipb.pt

1 Centro de Investigação de Montanha (CIMO), ESA, Instituto Politécnico de Bragança, Campus de Santa Apolónia, 5300-253 Bragança, Portugal

2 CEB - Centre for Biological Engineering, Universidade do Minho, 4710-057 Braga, Portugal
Dry-cured hams constitute one of the most representative traditional foods that are produced and consumed all over the world. The reduced water activity, salt content and $\mathrm{pH}$ achieved during processing and storage of these products usually render them safe, since they together inhibit the development of pathogenic bacteria. But these characteristics are also inductive of superficial colonization by fungi. The hygienic quality of raw materials, the manufacturing practices and the environmental factors (such as temperature and relative humidity) during ripening determine the type and growth rate of fungi growing on the surface of dry-cured meats. A complex mycobiota is generally observed on the surface of these products with Aspergillus, Eurotium and Penicillium as the most frequently isolated genera (Comi et al. 2004; Samson et al. 2004a; Battilani et al. 2007; Sørensen et al. 2008; Sonjak et al. 2011; Alapont et al. 2014). These fungi are generally assumed to improve taste and quality, due to their lipolytic and proteolytic activities (Ludemann et al. 2004; Martín et al. 2004, 2006; Sonjak et al. 2011). But, besides these features, the development of fungi may also lead to the accumulation of toxigenic secondary metabolites, namely mycotoxins such as ochratoxin A (OTA), aflatoxins (AFs) and others, which result in health hazards to the consumers. 
OTA has been frequently reported as contaminant of drycured meat products, either due to carry-over effects of animals exposed to contaminated feed (Dall'Asta et al. 2010; Pleadin et al. 2013) or to the growth of toxigenic fungi during ripening, which generally occurs under environmental conditions that are inductive of mycotoxin production (Iacumin et al. 2009, 2011; Rodríguez et al. 2012b). Aflatoxin $B_{1}$ $\left(\mathrm{AFB}_{1}\right)$ contamination has not been clearly associated with dry-cured hams, but aflatoxigenic species have been detected in these type of products (Comi et al. 2004), and their ability to produce this toxin has been reported by Rodríguez et al. (2012a).

OTA can be nephrotoxic, hepatotoxic, neurotoxic, teratogenic and immunotoxic (Petzinger and Ziegler 2000), and is produced by several species of Aspergillus and Penicillium (Vipotnik et al. 2017). AFs are a group of mutagenic, teratogenic and immunosuppressive mycotoxins that include the most widely studied $\mathrm{AFB}_{1}$. $\mathrm{AFB}_{1}$ is considered the most carcinogenic compound naturally produced, and is produced by some species belonging to Aspergillus section Flavi (Rodrigues et al. 2011). The International Agency for Research on Cancer (IARC 1993) has classified OTA as possible carcinogenic to humans (group $2 \mathrm{~B}$ ), while $\mathrm{AFB}_{1}$ is classified as carcinogenic (group 1). Mycotoxins have not been regulated by European legislation in meat and meat products. But OTA, and to a lesser extent AFs, have been detected in numerous meat products, like sausages, salami and dry-cured ham, in varying concentrations, as recently reviewed by Montanha et al. (2018).

The meat industry aims at developing innovative products to react to consumer's demand, and product's safety, including mould toxicity, is an underlying concern. The objectives of the present work were to reply to this concern, by surveying the contamination with OTA and AFB1 of several innovative meat products: long-ripe pork dry-cured hams (legs), pork dry-cured shoulders and goat and sheep dry-cured hams (legs). The fungi potentially responsible for this contamination were also studied.

\section{Materials and methods}

\section{Conditions of dry-cured ham production}

The fabrication process of sheep and goat legs (with approximate raw weight of $3 \mathrm{~kg}$ ) was made in three batches, one at LTQCC (Carcass and Meat Quality and Technology Laboratory of Agriculture School of Bragança, Polytechnic Institute of Bragança, Portugal) and two at Bísaro Salsicharia Tradicional (traditional production), and consisted of (1) salting, between 2 and $5{ }^{\circ} \mathrm{C}$ and relative humidity of 80 $90 \%$, for a period of 1 day of salting for each $1 \mathrm{~kg}$ of meat; (2) cleaning and washing; (3) curing and drying, 1 to 2 months at
$8-10{ }^{\circ} \mathrm{C}$ and relative humidity of $60-70 \%$; and (4) ripening, 7 to 8 months at $17-20^{\circ} \mathrm{C}$ and relative humidity of $60-70 \%$.

The fabrication process of pork dry-cured hams (legs with average weight of $19.2 \mathrm{~kg}$ ) and shoulders (with average weight of $10.4 \mathrm{~kg}$ ) took place at the industry Bísaro Salsicharia Tradicional and was made as follows: (1) salting, 2 and $4{ }^{\circ} \mathrm{C}$ and relative humidity of $90-95 \%$, for a period of 1 day of salting for each $1 \mathrm{~kg}$ of meat; (2) cleaning and washing; (3) drying-maturation, 6 months at $14-16^{\circ} \mathrm{C}$ and relative humidity of 55-75\%; and (4) ripening, $15-20^{\circ} \mathrm{C}$ and relative humidity of $65-75 \%$. Legs were cured for up to 25 months, and shoulders up to 15 months.

\section{Sampling}

Samples of pork legs were taken at two different stages: fresh (in the abattoir; $n=15), 14$ months of ripening $(n=9)$ and 20 25 months of ripening $(n=47)$. Samples of pork shoulders, sheep hams and goat hams were taken at the end of ripening: 13 to 15 months for pork shoulders $(n=40)$, and 8 months for sheep and goat legs ( $n=11$ and $n=21$, respectively).

Superficial pieces of meat (fresh meat or dry-cured ham) with 3 to $4 \mathrm{~cm}$ depth were cut from the meat pieces and put in sterile bags. Samples were immediately transported to the laboratory and preserved at $4{ }^{\circ} \mathrm{C}$ for up to 3 days until mycological analysis, and at $-18{ }^{\circ} \mathrm{C}$ until mycotoxin analysis. The measurement of $\mathrm{pH}$ was performed according to the Portuguese standard NP-ISO 3441 (2008) using a potentiometer with an electrode equipped with a penetrator cell calibrated. Water activity was assessed with an aw probe (HygroPalm Aw1 rotronic 8303, Basserdorf, Switzerland) according to AOAC (1990).

\section{Mycological analysis}

\section{Fungal isolation}

Fungal contamination of dry-cured hams was determined by swabbing a surface of approximately $100 \mathrm{~cm}^{2}$. Samples were plated in Dichloran Rose Bengal Chloramphenicol (DRBC, Oxoid) and Dichloran Glycerol 18\% (DG18, Merck), and incubated at $25{ }^{\circ} \mathrm{C}$ in the dark for 7 days. After incubation, representative isolates of genera Aspergillus and Penicillium were isolated as described by Rodrigues et al. (2013) and grouped in morphotypes.

\section{Fungal identification}

Morphological identification followed the taxonomic keys and guides available for genera Aspergillus and Penicillium (Klich 2002; Frisvad and Samson 2004; Samson et al. 2004a; Samson and Varga 2007; Pitt and Hocking 2009; Samson and Houbraken 2011; Samson et al. 2011). All isolates were 
screened for AFs and OTA production by thin-layer chromatography (TLC) as described by Samson et al. (2004b). Those showing fluorescence (LOD $=2 \mathrm{ng} / \mathrm{spot}$ ) were considered positive and were confirmed by HPLC (Rodrigues et al. 2011; Vipotnik et al. 2017).

For the molecular identification of fungi, genomic DNA of the selected isolates $(n=186)$ was obtained as described by Rodrigues et al. (2018). Isolates were grouped based on genomic fingerprinting by enterobacterial repetitive intergenic consensus PCR (ERIC-PCR) following Alves et al. (2007), and at least two isolates representative of each group were further identified by DNA sequencing following Rodrigues et al. (2011), in a total of 54 sequenced isolates.

\section{Aflatoxin $B_{1}$ and ochratoxin $A$ analyses of meat samples by HPLC-FLD}

\section{Chemicals and materials}

The standard solution of $\mathrm{AFB}_{1}$ was purchased from SigmaAldrich (St. Louis, USA), and OTA standard solution was from AppliChem (Darmstadt, Germany). HPLC grade solvents (methanol and acetonitrile) were used in the preparation of mycotoxin standards, in sample extraction and in the preparation of mobile phase. For extract purification of $\mathrm{AFB}_{1}$ and OTA, AflaTest WB and OchraTest WB immunoaffinity columns (IACs) were obtained from VICAM (Watertown, MA, USA). Phosphate buffer saline $0.1 \mathrm{M}$ with Tween 80 (PBS-T) pH 7.0 was prepared by adding $500 \mathrm{~mL}$ of $0.1 \mathrm{M} \mathrm{NaH}_{2} \mathrm{PO}_{4}$, $500 \mathrm{~mL}$ of $0.1 \mathrm{M} \mathrm{Na}_{2} \mathrm{HPO}_{4} \cdot 12 \mathrm{H}_{2} \mathrm{O}$ and $0.1 \%$ Tween 80 . All necessary safety considerations were taken when handling mycotoxins (Pereira et al. 2017).

\section{Aflatoxin $\mathrm{B}_{1}$ and OTA co-extraction}

$\mathrm{AFB}_{1}$ and OTA were co-extracted following the methodology for OTA extraction proposed by Chiavaro et al. (2002), with some modifications. Comminuted samples $(10 \mathrm{~g})$ were added to $40 \mathrm{~mL}$ of methanol:1\% sodium bicarbonate $(70: 30, \mathrm{v} / \mathrm{v})$ and stirred for $30 \mathrm{~min}$. The filtered extract $(10 \mathrm{~mL})$ was diluted with $40 \mathrm{~mL}$ of $0.1 \mathrm{M}$ PBS-T $\mathrm{pH} 7$ and further filtered through a glass microfibre filter. The extract was divided into two portions used to purify each of the mycotoxins $\mathrm{AFB}_{1}$ and OTA with IAC. Twenty millilitres of the extract were passed through each IAC by gravity, at a rate of about 1-2 drops/s and further processed as recommended by the manufacturer. AFs and OTA were eluted from the IAC with $2 \mathrm{~mL}$ of HPLC grade methanol.

\section{Mycotoxin detection and quantification by HPLC-FLD}

Chromatographic separations of $\mathrm{AFB}_{1}$ and OTA were performed independently, by high performance liquid chromatography coupled to a fluorescence detector (HPLCFLD) using the conditions described by Pereira et al. (2017).

\section{In-house HPLC methods validation}

Different sets of standard solutions and of spiked samples were used for the validation of the $\mathrm{AFB}_{1}$ and OTA extraction methods. Precision and recovery were performed by spiking blank samples with $10 \mu \mathrm{g} / \mathrm{kg}$ of both $\mathrm{AFB}_{1}$ and OTA. Each sample set was composed of six replicates, tested in two different days.

Linearity, limit of detection (LOD) and limit of quantification (LOQ) were determined by three series of analyses. For OTA, seven standard solutions were used, at concentrations from 0.5 to $15.0 \mathrm{ng} / \mathrm{mL}$. For $\mathrm{AFB}_{1}, 5$ standard solutions were used, at concentrations from 0.5 to $15.6 \mathrm{ng} / \mathrm{mL}$. The calibration curves for each mycotoxin revealed linear relationships $\left(r^{2}=0.996\right.$ and 0.998 for OTA and $\mathrm{AFB}_{1}$ respectively). LOD and LOQ were calculated as 0.3 and $0.9 \mu \mathrm{g} / \mathrm{kg}$ for OTA, and 0.5 and $1.5 \mu \mathrm{g} / \mathrm{kg}$ for $\mathrm{AFB}_{1}$, respectively. Recovery rates of $\mathrm{OTA}$ and $\mathrm{AFB}_{1}$ were calculated by the ratio of recovered mycotoxin concentration relative to the spiked concentration. Precision was calculated in terms of intra-day repeatability $(n=3)$ and intermediate precision (inter-day within-laboratory reproducibility; $n=6$ ). Recovery rate, performance and precision of the extraction method are presented in Table 1. In-house method validation demonstrated the conformity of the method for OTA and $\mathrm{AFB}_{1}$ analysis with provisions of Regulation (EC) no. 401/2006 (EC 2006a).

\section{Results and discussion}

\section{Physico-chemical characterization of samples}

$\mathrm{pH}$ and aw of the various types of cured products (pork, goat and sheep legs and pork shoulders) at the end of the curing period are presented in Table 2.

Table 1 Recovery, performance and precision of aflatoxin $\mathrm{B}_{1}$ and ochratoxin A extraction method for spiking with $10 \mu \mathrm{g} / \mathrm{kg}$ of each mycotoxin

\begin{tabular}{llll}
\hline & Fresh meat & \multicolumn{2}{l}{ Ham } \\
\cline { 3 - 4 } & OTA & OTA & $\mathrm{AFB}_{1}$ \\
\hline Recovery at $10 \mu \mathrm{g} / \mathrm{kg}(\%)$ & 115.5 & 100.9 & 97.9 \\
Repeatability $\left(\mathrm{RSD}_{\mathrm{r}} ; n=3\right)$ & 1.3 & 1.8 & 15.9 \\
Intermediate precision $\left(\mathrm{RMD}_{\mathrm{INT}} ; n=6\right)$ & 1.1 & 1.7 & 16.1 \\
\hline
\end{tabular}


Table $2 \mathrm{pH}$ and aw (average \pm standard deviation) of pork, goat and sheep cured legs, and porkcured shoulder

\begin{tabular}{llllll}
\hline $\begin{array}{l}\text { Category of } \\
\text { product }\end{array}$ & Pork leg & & Pork shoulder & Goat leg & Sheep leg \\
$\begin{array}{l}\text { Curing period } \# \\
\text { samples })\end{array}$ & $\begin{array}{l}14 \text { months } \\
(n=9)\end{array}$ & $\begin{array}{l}20-25 \text { months } \\
(\mathrm{n}=47)\end{array}$ & $\begin{array}{l}13-15 \text { months } \\
(n=40)\end{array}$ & $\begin{array}{l}8 \text { months } \\
(n=21)\end{array}$ & $\begin{array}{l}8 \text { months } \\
(n=11)\end{array}$ \\
\hline pH & $6.00 \pm 0.07$ & $5.93 \pm 0.18$ & $5.91 \pm 0.16$ & $6.07 \pm 0.09$ & $5.89 \pm 0.12$ \\
aw & $0.91 \pm 0.01$ & $0.89 \pm 0.01$ & $0.86 \pm 0.01$ & $0.84 \pm 0.06$ & $0.90 \pm 0.03$ \\
\hline
\end{tabular}

\section{Mycobiota of meat samples}

A total of 630 fungi (334 from pork leg, 126 from pork shoulder, 118 from goat and 52 from sheep) were isolated and grouped by morphotypes, and 186 of these fungi were molecularly identified. The identified fungal species, as well as their incidence in each product category (determined as number of samples of each category contaminated with at least one isolate of the species) and the ability to produce AFs and OTA are shown in Table 3. Penicillium isolates dominated the fungal population in all products ( $66 \%$ of the total isolates), followed by Aspergillus (34\%).

The high incidence of Penicillium is supported by other studies on dry-cured hams and similar products (Nuñez et al. 1996; Comi et al. 2004; Battilani et al. 2007; Asefa et al. 2009; Sonjak et al. 2011; Alapont et al. 2014) given the ripening conditions of these products. The predominantly isolated species was $P$. commune, which corresponded to $53 \%$ of all isolates, and was detected in all samples. P. commune has generally been reported in very high frequencies in other studies (Nuñez et al. 1996; Comi et al. 2004; Battilani et al. 2007; Asefa et al. 2009; Sonjak et al. 2011; Alapont et al. 2014), and it is a cyclopiazonic acid (CPA) producing species (Frisvad and Samson 2004).

Other species with overall high incidence in our samples are also associated with mycotoxin production: P. brevicompactum (mycophenolic acid), P. carneum (mycophenolic acid, patulin, roquefortin $\mathrm{C}$ and penitrem $\mathrm{A}$ ), P. chrysogenum (PR-toxin and roquefortin C), P. coprobium (patulin and roquefortin) C (Frisvad and Samson 2004).

$P$. nordicum, which was detected in low amounts and in pork samples only (four isolates in 20-25 months pork legs and one isolate in pork shoulders), is a producer of OTA, and is a common contaminant of protein-rich foods, which can grow well at low temperatures $\left(15^{\circ} \mathrm{C}\right)$ and increased salt content (>5\% NaCl) (Dall'Asta et al. 2010; Sonjak et al. 2011; Ferrara et al. 2015; Vipotnik et al. 2017). For this reason, foods like dry-cured ham and related meat products are typical habitats of this species (Larsen et al. 2001; Bogs et al. 2006) and it is generally considered the major risk in terms of mycotoxin contamination.

Considering the Aspergillus genus, it was less frequently isolated than Penicillium, as also reported by others (Comi et al. 2004; Sonjak et al. 2011; Alapont et al. 2014). Only six Aspergillus species were isolated from the samples, representing $31 \%$ of all isolates. The succession of Aspergillus species throughout ripening followed an expected trend: longer ripening processes led to the reduction of less xerophilic aflatoxigenic species (A. flavus, A. parasiticus and A. nomius) and to an increase in the more xerophilic ones (A. proliferans and A. pseudoglaucus). Among the aflatoxigenic species, A. flavus was detected in all animal sources, with higher incidence in the less ripened products $(100 \%)$. On the other hand, A. parasiticus was detected only in goat and sheep samples with low representation, and A. nomius was detected in sheep samples only. To our knowledge, this is the first report of these two species in dry-cured hams. All isolates belonging to these three species were tested for their aflatoxin production ability. All A. parasiticus and A. nomius isolates were strong AFB and AFG producers, but only $11 \%$ of the A. flavus isolates were able to produce AFB, and at lower amounts than the other two species, as also described for isolates from other sources (Rodrigues et al. 2011).

In the present study, A. westerdijkiae was detected in one 20-month ripened pork leg sample. Other types of cured meat products seem to be more affected by this fungus, as Iacumin et al. (2011) and Canel et al. (2013) reported that up to $34 \%$ and $93 \%$, respectively, of Italian sausage casings were contaminated with A. ochraceus/ A. westerdijkiae. More recently, Merla et al. (2018) also reported the identification of three $A$. westerdijkiae isolates in Italian traditional salami samples. Given its relatively low detection, $A$. westerdijkiae has rarely been studied as a potential risk of OTA contamination in ripened meat products. Nonetheless, A. westerdijkiae has been recently reported to be well adapted to dry-cured ham and other ripened meat products (Vipotnik et al. 2017; Meftah et al. 2018; Merla et al. 2018), and should be considered a high sanitary risk in products of animal origin with high salt content, such as dry-cured ham (Vipotnik et al. 2017).

\section{Mycotoxin contamination of meat samples}

The results of OTA contamination of pork fresh meat and drycured ham samples are shown in Table 4. OTA was not detected in any of the goat and sheep samples. No $\mathrm{AFB}_{1}$ was detected in any of the pork, goat and sheep samples. 
Table 3 Representative mycobiota isolated from cured ham samples: total number of isolates, incidence (samples contaminated with the species, in percentage) and mycotoxin production ability (in bold, the detected aflatoxigenic and ochratoxigenic species, confirmed by HPLC)

\begin{tabular}{|c|c|c|c|c|c|c|}
\hline Category of product & Pork leg & Pork leg & Pork shoulder & Goat & Sheep & Mycotoxin production \\
\hline $\begin{array}{l}\text { Curing period } \\
\text { (\# samples) }\end{array}$ & $\begin{array}{c}14 \text { months } \\
\quad(n=9)\end{array}$ & $\begin{array}{l}20-25 \text { months } \\
(n=47)\end{array}$ & $\begin{array}{l}13-15 \text { months } \\
(n=40)\end{array}$ & $\begin{array}{l}3 \text { months } \\
\quad(n=21)\end{array}$ & $\begin{array}{l}3 \text { months } \\
\quad(n=11)\end{array}$ & \\
\hline A. flavus & $30(100 \%)$ & $14(30 \%)$ & $8(20 \%)$ & $30(100 \%)$ & $13(100 \%)$ & Aflatoxins B (11\% positive) \\
\hline A. nomius & - & - & - & - & $3(27 \%)$ & $\begin{array}{l}\text { Aflatoxins } B+G(100 \% \\
\text { positive })\end{array}$ \\
\hline A. parasiticus & - & - & - & $5(24 \%)$ & $3(27 \%)$ & $\begin{array}{l}\text { Aflatoxins } B+G(100 \% \\
\text { positive })\end{array}$ \\
\hline A. proliferans & $11(100 \%)$ & $58(100 \%)$ & $4(10 \%)$ & $6(29 \%)$ & $4(36 \%)$ & n.d. \\
\hline A. pseudoglaucus & - & $5(11 \%)$ & - & - & - & n.d. \\
\hline A. westerdijkiae & - & $1(2 \%)$ & - & - & - & Ochratoxin A (positive) \\
\hline Total Aspergillus & 41 & 78 & 12 & 41 & 23 & \\
\hline P. aethopicum & $1(11 \%)$ & - & $2(5 \%)$ & - & - & n.d. \\
\hline P. brevicompactum & - & $2(4 \%)$ & $4(10 \%)$ & $3(14 \%)$ & $1(9 \%)$ & n.d. \\
\hline P. carneum & - & $13(28 \%)$ & - & $5(24)$ & $2(18 \%)$ & n.d. \\
\hline P. chrysogenum & $3(33 \%)$ & - & - & $7(33 \%)$ & $3(27 \%)$ & n.d. \\
\hline P. citrinum & - & $2(4)$ & - & - & - & n.d. \\
\hline P. commune & $20(100 \%)$ & $92(100 \%)$ & $75(100 \%)$ & $25(100 \%)$ & $12(100 \%)$ & n.d. \\
\hline P. coprobium & $3(33 \%)$ & $21(45 \%)$ & $13(33 \%)$ & & & n.d. \\
\hline P. crustosum & $5(56 \%)$ & $6(13 \%)$ & $4(10 \%)$ & $5(24 \%)$ & $9(82 \%)$ & n.d. \\
\hline P. cyclopium & - & - & - & $11(52 \%)$ & - & n.d. \\
\hline P. echinulatum & - & $4(9 \%)$ & $15(38 \%)$ & $21(100 \%)$ & - & n.d. \\
\hline P. nalgiovense & - & - & - & - & $1(9 \%)$ & n.d. \\
\hline P. nordicum & - & $4(9 \%)$ & $1(3 \%)$ & - & - & Ochratoxin A ( $100 \%$ positive) \\
\hline P. polonicum & - & $13(28 \%)$ & - & - & - & n.d. \\
\hline P. solitum & $1(11 \%)$ & $12(26 \%)$ & - & - & $1(9 \%)$ & n.d. \\
\hline P. thymicola & - & $9(19 \%)$ & - & - & - & n.d. \\
\hline P. viridicatum & - & $4(9 \%)$ & - & - & - & n.d. \\
\hline Total Penicillium & 33 & 182 & 114 & 77 & 29 & \\
\hline Total fungal isolates & 74 & 260 & 126 & 118 & 52 & \\
\hline
\end{tabular}

n.d. AFs and OTA not detected

Dall'Asta et al. (2010) reported mycotoxin accumulation in body fluids (blood and urine) and tissues (muscle, kidney, liver) at relatively low concentrations in animals fed with contaminated feedstuffs. Our results showed that as much as $40 \%$ of the fresh pork leg samples were contaminated with detectable levels of OTA (but below the limit of
Table 4 Quantification of ochratoxin A (in $\mu \mathrm{g} / \mathrm{kg}$ ) of pork dry-cured ham samples

\begin{tabular}{lllll}
\hline Category of product & Fresh meat & Leg & Shoulder \\
\hline Curing period (months) & 0 & 14 & $20-25$ & $13-15$ \\
\# samples & 15 & 9 & 47 & 40 \\
\# positive samples $(>\mathrm{LOD})$ & 6 & 1 & 20 & 7 \\
$\%$ positive samples & 40 & 11 & 43 & 18 \\
Mean OTA $(\mu \mathrm{g} / \mathrm{kg} \pm \mathrm{SD})(>\mathrm{LOQ})$ & $<$ LOQ & $<$ LOQ & $14.9 \pm 27.9$ & $6.6 \pm 6.2$ \\
Median OTA $(\mu \mathrm{g} / \mathrm{kg})(>\mathrm{LOQ})$ & - & - & 3.3 & 5.2 \\
Min-max OTA $(\mu \mathrm{g} / \mathrm{kg})$ & $<$ LOQ & $<$ LOQ & $<$ LOQ-99.1 & $<$ LOQ-14.7 \\
\hline
\end{tabular}

$\angle O D$ limit of detection

$L O Q$ limit of quantification

$S D$ standard deviation 
quantification, $0.9 \mu \mathrm{g} / \mathrm{kg}$ ), denoting a limited level of OTA carry-over into pork muscle. In fact, the real risk due to a carry-over from OTA-contaminated feed to pork meat has been considered negligible by the European Food Safety Authority (EFSA-Q-2003-039 2004), due to the generally low level of contamination of animal feed in Europe.

On the other side, the long ripening periods to which cured meat products are subjected, as well as their intrinsic features (low aw and $\mathrm{pH}$, high salt content) are conducive to the growth of numerous fungi on the food surface, and to the potential production of mycotoxins. In the present study, $29 \%$ of all pork dry-cured ham samples were found to be contaminated with OTA. Of these, $21 \%$ were contaminated with more than $1 \mu \mathrm{g} / \mathrm{kg}$ of OTA.

Under the Regulation 1881/2006/EC (EC 2006b), the Commission of the European Communities defined OTA maximum permissible levels (MPLs) in different foodstuffs and underlines the importance of defining OTA MPLs in other products, meat products included. However, no European regulation on OTA contamination of meat products has emerged, and Italy is currently the only EU country where guidelines for the maximal recommended OTA level of $1 \mu \mathrm{g} / \mathrm{kg}$ in pork and pork-derived products have been provided by the Ministero della Sanità (1999).

In our study, the five isolates of $P$. nordicum originated from different cured meat samples showing levels of OTA ranging from <LOQ to $5.9 \mu \mathrm{g} / \mathrm{kg}$. The sample showing the highest level of OTA contamination $(99 \mu \mathrm{g} / \mathrm{kg})$ was the one from where A. westerdijkiae was isolated. Iacumin et al. (2011) found that $34 \%$ of casings of Italian sausages showing high levels of OTA were contaminated with A. ochraceus (possibly A. westerdijkiae). More recently, Merla et al. (2018) reported 10\% (13) of OTA-contaminated samples from Italian salami and, with the exception of one sample, samples contaminated with A. westerdijkiae showed the highest levels of OTA contamination. In two previous reports (Vipotnik et al. 2017; Meftah et al. 2018), it was possible to determine the strong ability of this species to produce OTA in dry-cured meat products under a wide range of environmental conditions. More than that, these studies showed that this fungus produces OTA in much higher levels and in a wider range of temperature and water activity than the widely studied $P$. nordicum, and its ochratoxigenic ability can be stimulated by the presence of other existing or added microbiota (Meftah et al. 2018). In the study by Vipotnik et al. (2017), P. nordicum produced OTA over a narrow range of selected conditions ( 0.97 aw, $3 \%$ salt, between 15 and $\left.20{ }^{\circ} \mathrm{C}\right)$, while A. westerdijkiae was able to produce OTA over a wider range of aw and temperature conditions, with optimum conditions at $0.97-0.93$ aw (3-6\% salt) at all temperatures, with maximum at $20-24{ }^{\circ} \mathrm{C}$. Considering the ripening conditions of the various types of cured products $\left(17-20^{\circ} \mathrm{C}\right.$ for sheep and goat legs; $15-20^{\circ} \mathrm{C}$ for pork legs and shoulders) as well as their intrinsic conditions (shown in Table 2) of low aw ( 0.90 for sheep, 0.84 for goat and between 0.89 and 0.91 for pork legs and shoulders) and slightly acidic $\mathrm{pH}$ (around 6.0 for all species), the two fungi find adequate conditions for growth and OTA production in all of them. The fact that no contamination was detected in goat and sheep samples can to be due to the apparent absence of ochratoxigenic fungi. Also, these legs are smaller than pork pieces, with shorter ripening periods. Their aw reduces rapidly (in average from 0.98 to 0.91 in the first $24 \mathrm{~h}$ after salting; Teixeira et al. 2017), which is a limiting factor for OTA production. On the other side, pork pieces, being larger, take longer to reduce aw to safe values, and that might be the reason for higher levels of OTA contamination.

In what concerns aflatoxin contamination, Pleadin et al. (2015) results showed the risk of $\mathrm{AFB}_{1}$ presence in fresh meat products to be minimal, and it is assumed that a low rate of carry-over to edible tissues occurs, given that $\mathrm{AFB}_{1}$ primarily targets the liver (Markov et al. 2013). For that reason, $\mathrm{AFB}_{1}$ contamination of fresh pork meat was not determined in our study. On the other side, the hazard of $\mathrm{AFB}_{1}$ production on ripened meat products as dry-cured ham has been demonstrated previously in model systems (Rodríguez et al. 2012a), where the inoculated aflatoxigenic fungi were able to produce high amounts of this toxin at both high and low aw (0.92 and 0.84 ). In our study, however, the high incidence of aflatoxigenic fungi in all types of products was not translated into $\mathrm{AFB}_{1}$ sample contamination. Goat and sheep samples were contaminated with a low number of the strong aflatoxin producers A. parasiticus and A. nomius, but the presence of non-aflatoxigenic strains of $A$. flavus was much more significant. In pork samples, only A. flavus strains were detected, and only a low proportion of these were aflatoxigenic.

The ability of fungi to produce toxins is highly dependent on intrinsic as well as environmental conditions, as has been proven widely (Nuñez et al. 2007; Vipotnik et al. 2017; Meftah et al. 2018), and for such reason not all toxigenic fungi can be considered a real risk in all food matrices. This seems to happen with $\mathrm{AFs}$ production in dry-cured hams. AFs production has been determined to occur at temperatures between 20 and $37^{\circ} \mathrm{C}$, and for aw $>0.85$, but they were found to be optimally produced at $28-30{ }^{\circ} \mathrm{C}$ and $>0.95$ (Schmidt-Heydt et al. 2009). These conditions are not concordant with the observed conditions during ripening.

The fact that OTA was found in pork products only provides a hint with regard to the source of contamination. In the present study, only six OTA producing fungal isolates $(1 \times$ A. westerdijkiae, $5 \times P$. nordicum) were obtained, all from pork samples. This means that there were 22 OTAcontaminated pork samples from which no ochratoxigenic fungal isolates could have been obtained. The most plausible explanation for this finding would be primary contamination, meaning an in vivo carry-over of OTA from swine feed into swine blood and tissues. Limitations of culture-dependent 
methods of fungal detection and consequently qualitative and quantitative underestimation could be another explanation for undetected secondary contamination.

Funding information Work was funded by the Portuguese PRODER research Project number 020260013013 "New goat and sheep processed meat products" and BISOVICAP_-Processing meat from pigs, sheep and goats, to produce new products. Ham and pâté, Project PROTEC, SI I\&DT-Projects in Co-Promotion, no. 21511. The authors received support from the Laboratory of Carcass and Meat Quality of Agriculture School of Polytechnic Institute of Bragança 'Cantinho do Alfredo' and from MARCARNE network, funded by CYTED (ref. 116RT0503). The authors also received financial support from the Foundation for Science and Technology (FCT, Portugal) and FEDER under Programme PT2020 to CIMO (UID/AGR/00690/2019). CEB also received support from FCT under the scope of the strategic funding of UID/BIO/04469/2019 unit, and BioTecNorte operation (NORTE-01-0145-FEDER-000004), funded by the European Regional Development Fund under the scope of Norte2020 - Programa Operacional Regional do Norte.

\section{Compliance with ethical standards}

Conflict of interest The authors declare that they have no conflict of interest.

\section{References}

Alapont C, López-Mendoza MC, Gil JV, Martínez-Culebras PV (2014) Mycobiota and toxigenic Penicillium species on two Spanish drycured ham manufacturing plants. Food Addit Contam part A 31:93104

Alves A, Phillips AJL, Henriques I, Correia A (2007) Rapid differentiation of species of Botryosphaeriaceae by PCR fingerprinting. Res Microbiol 158:112-121

AOAC (1990) AOAC official methods of analysis (15th ed.). Washington, DC: Association of Official Analytical Chemists

Asefa DT, Gjerde RO, Sidhu MS, Langsrud S, Kure CF, Nesbakken T, Skaar I (2009) Moulds contaminants on Norwegian dry-cured meat products. Int J Food Microbiol 128:435-439

Battilani P, Pietri VA, Giorni P, Formenti S, Bertuzzi T, Toscani T, Virgili R, Kozakiewicz Z (2007) Penicillium populations in dry-cured ham manufacturing plants. J Food Prot 70:975-980

Bogs C, Battilani P, Geisen R (2006) Development of a molecular detection and differentiation system for ochratoxin A producing Penicillium species and its application to analyse the occurrence of Penicillium nordicum in cured meats. Int J Food Microbiol 107:3947

Canel RS, Wagner JR, Stenglein SA, Ludemann V (2013) Indigenous filamentous fungi on the surface of Argentinean dry fermented sausages produced in Colonia Caroya (Córdoba). Int J Food Microbiol 164:81-86

Chiavaro E, Lepiani A, Colla F, Bettoni P, Pari E, Spotti E (2002) Ochratoxin A determination in ham by immunoaffinity clean-up and a quick fluorometric method. Food Addit Contam 19:575-581

Comi G, Orlic S, Redzepovic S, Urso R, Iacumin L (2004) Moulds isolated from Istrian dried ham at the pre-ripening and ripening level. Int J Food Microbiol 96:29-34

Dall'Asta C, Galaverna G, Bertuzzi T, Noseriti A, Pietri A, Dossena A, Marchelli R (2010) Occurrence of ochratoxin A in raw ham muscle, salami and dry-cured ham from pigs fed with contaminated diet. Food Chem 120:978-983
EC (2006a) Commission Regulation (EC) No 401/2006 of 23 February laying down the methods of sampling and analysis for the official control of the levels of mycotoxins in foodstuffs. Off $\mathrm{J}$ Eur Union L70/12-L70-34

EC (2006b) Commission Regulation (EC) No 1881/2006 of 19 December 2006, setting maximum levels for certain contaminants in foodstuffs. Off J Eur Union L364/5-L364-24

EFSA-Q-2003-039 (2004) Opinion of the scientific panel on contaminants in food chain on a request from the commission related to ochratoxin A (OTA) as undesirable substance in animal feed. EFSA (European Food Safety Authority). EFSA J 101:1-36

Ferrara M, Perrone G, Gallo A, Epifani F, Visconti A, Susca A (2015) Development of loop-mediated isothermal amplification (LAMP) assay for the rapid detection of Penicillium nordicum in dry-cured meat products. Int J Food Microbiol 202:42-47

Frisvad JC, Samson RA (2004) Polyphasic taxonomy of Penicillium subgenus Penicillium - a guide to identification of food and airborne terverticillate Penicillia and their mycotoxins. Stud Mycol 49: $1-173$

Iacumin L, Chiesa L, Boscolo D, Manzano M, Cantoni C, Orlic S, Comi G (2009) Moulds and ochratoxin A on surfaces of artisanal and industrial dry sausages. Food Microbiol 26:65-70

Iacumin L, Milesi S, Pirani S, Comi G, Chiesa LM (2011) Ochratoxigenic mold and ochratoxin a in fermented sausages from different areas in northern Italy: occurrence, reduction or prevention with ozonated air. J Food Saf 31:538-545

IARC (1993) Some naturally occurring substances: food items and constituents, heterocyclic aromatic amines and mycotoxins. In: International Agency for Research on Cancer, World Health Organization (ed) IARC monographs on the evaluation of carcinogenic risks to humans. Lyon, France: IARC Press 56:599

Klich MA (2002) Identification of common Aspergillus species. CBS, The Netherlands

Larsen TO, Svendsen A, Smedsgaard J (2001) Biochemical characterization of ochratoxin A-producing strains of the genus Penicillium. Appl Environ Microbiol 67:3630-3363

Ludemann V, Pose G, Pollio ML, Segura J (2004) Determination of growth characteristics and lipolytic and proteolytic activities of Penicillium strains isolated from Argentinean salami. Int J Food Microbiol 96:13-18

Markov K, Pleadin J, Bevardi M, Vahčić N, Sokolić-Mihalak D, Frece J (2013) Natural occurrence of aflatoxin B1, ochratoxin A and citrinin in Croatian fermented meat products. Food Control 34:312-317

Martín A, Córdoba JJ, Núñez F, Benito MJ, Asensio MA (2004) Contribution of a selected fungal population to proteolysis on drycured ham. Int J Food Microbiol 94:55-66

Martín A, Córdoba JJ, Aranda E, Córdoba MG, Asensio MA (2006) Contribution of a selected fungal population to the volatile compounds on dry-cured ham. Int J Food Microbiol 110:8-18

Meftah S, Abid S, Dias T, Rodrigues P (2018) Effect of dry-sausage starter culture and endogenous yeasts on Aspergillus westerdijkiae and Penicillium nordicum growth and OTA production. LWT Food Sci Technol 87:250-258

Merla C, Andreoli G, Garino C, Tosi G, Guglielminetti ML, Moretti A, Biancardi A, Arlorio M, Fabbi M (2018) Monitoring of ochratoxin $\mathrm{A}$ and ochratoxin- producing fungi in traditional salami manufactured in Northern Italy. Mycotox Res 34:107-116

Ministero della Sanità (1999) Circolare 09.06.1999. In M. D. Sanità (Ed.), Circolare 09.06.1999 (vol. 135) 11.06.1999. Gazzetta Ufficiale Repubblica Italiana

Montanha FP, Anater A, Burchard JF, Luciano FB, Meca G, Manyes L, Pimpão CT (2018) Mycotoxins in dry-cured meats: a review. Food Chem Toxicol 111:494-502

Nuñez F, Rodríguez MM, Bermúdez ME, Córdoba JJ, Asensio MA (1996) Composition and toxigenic potential of the mold population on dry-cured Iberian ham. Int J Food Microbiol 32:185-197 
Nuñez F, Westphal CD, Bermúdez E, Asensio MA (2007) Production of secondary metabolites by some terverticillate penicillia on carbohydrate-rich and meat substrates. J Food Prot 70:2829-2836

Paulos K, Rodrigues S, Oliveira AF, Leite A, Pereira E, Teixeira A (2015) Sensory characterization and consumer preference mapping of fresh sausages manufactured with goat and sheep meat. J Food Sci 80: S1568-S1573

Pereira E, Barros L, Antonio AL, Cabo Verde S, Santos-Buelga C, Ferreira ICFR, Rodrigues P (2017) Is gamma radiation suitable to preserve phenolic compounds and to decontaminate mycotoxins in aromatic plants? A case-study with Aloysia citrodora Paláu. Molecules 22(3):347

Petzinger E, Ziegler K (2000) Ochratoxin A from a toxicological perspective. J Vet Pharmacol Ther 23:91-98

Pitt JI, Hocking AD (2009) Fungi and food spoilage, 3rd edn. Springer $519 \mathrm{pp}$

Pleadin J, Perši N, Kovačevic D, Vahčić N, Scortichini G, Milone S (2013) Ochratoxin A in traditional dry-cured meat products produced from sub-chronic-exposed pigs. Food Addit Contam part A 30:1827-1836

Pleadin J, Staver MM, Vahčić N, Kovačevic D, Milone S, Saftić L, Scortichini G (2015) Survey of aflatoxin B1 and ochratoxin A occurrence in traditional meat products coming from Croatian households and markets. Food Control 52:71-77

Rodrigues P, Santos C, Venâncio A, Lima N (2011) Species identification of Aspergillus section Flavi isolates from Portuguese almonds using phenotypic, including MALDI-TOF ICMS, and molecular approaches. J Appl Microbiol 111:877-892

Rodrigues P, Venâncio A, Lima N (2013) Incidence and diversity of the fungal genera Aspergillus and Penicillium in Portuguese almonds and chestnuts. Eur J Plant Pathol 137:197-209

Rodrigues P, Venâncio A, Lima N (2018) Toxic reagents and expensive equipment: are they really necessary for the extraction of good quality fungal DNA? Lett Appl Microbiol 66:32-37

Rodríguez A, Rodríguez M, Martín A, Nuñez F, Córdoba JJ (2012a) Evaluation of hazard of aflatoxin B1, ochratoxin A and patulin production in dry-cured ham and early detection of producing molds by pPCR. Food Control 27:118-126
Rodríguez A, Rodríguez M, Martín A, Delgado J, Córdoba JJ (2012b) Presence of ochratoxin A on the surface of dry-cured Iberian ham after initial fungal growth in the drying stage. Meat Sci 92:728-734

Samson RA, Houbraken J (eds.) (2011) Phylogenetic and taxonomic studies on the genera Penicillium and Talaromyces. Stud Mycol 70:183

Samson RA, Varga J (eds.) (2007) Aspergillus systematics in the genomic era. Stud Mycol 59:206

Samson RA, Hoekstra ES, Frisvad JC (2004a) Identification of the common food- and airborne fungi. In: Samson RA, Hoekstra ES, Frisvad JC (eds) Introduction to food- and airborne fungi, 7th edn. CBS, The Netherlands, pp 1-282

Samson RA, Hoekstra ES, Lund F, Filtenborg O, Frisvad JC (2004b) Methods for the detection, isolation and characterisation of foodborne fungi. In: Samson RA, Hoekstra ES, Frisvad JC (eds) Introduction to food- and airborne fungi, 7 th edn. CBS, The Netherlands, pp 283-297

Samson RA, Varga J, Frisvad JC (eds) (2011) Taxonomic studies on the genus Aspergillus. Stud Mycol 69:97

Schmidt-Heydt M, Abdel-Hadi A, Magan N, Geisen R (2009) Complex regulation of the aflatoxin biosynthesis gene cluster of Aspergillus flavus in relation to various combinations of water activity and temperature. Int J Food Microbiol 135:231-237

Sonjak S, Ličen M, Frisvald JC, Gunde-Cimerman N (2011) The mycobiota of three dry-cured meat products from Slovenia. Food Microbiol 28:373-376

Sørensen LM, Jacobsen T, Nielsen PV, Frisvad JC, Koch AG (2008) Mycobiota in the processing areas of two different meat products. Int J Food Microbiol 124:58-64

Teixeira A, Fernandes A, Pereira E, Manuel A, Rodrigues S (2017) Effect of salting and ripening on the physicochemical and sensory quality of goat and sheep cured legs. Meat Sci 134:163-169

Vipotnik Z, Rodríguez A, Rodrigues P (2017) Aspergillus westerdijkiae as a major ochratoxin A risk in dry-cured ham based-media. Int J Food Microbiol 241:244-251

Publisher's note Springer Nature remains neutral with regard to jurisdictional claims in published maps and institutional affiliations. 